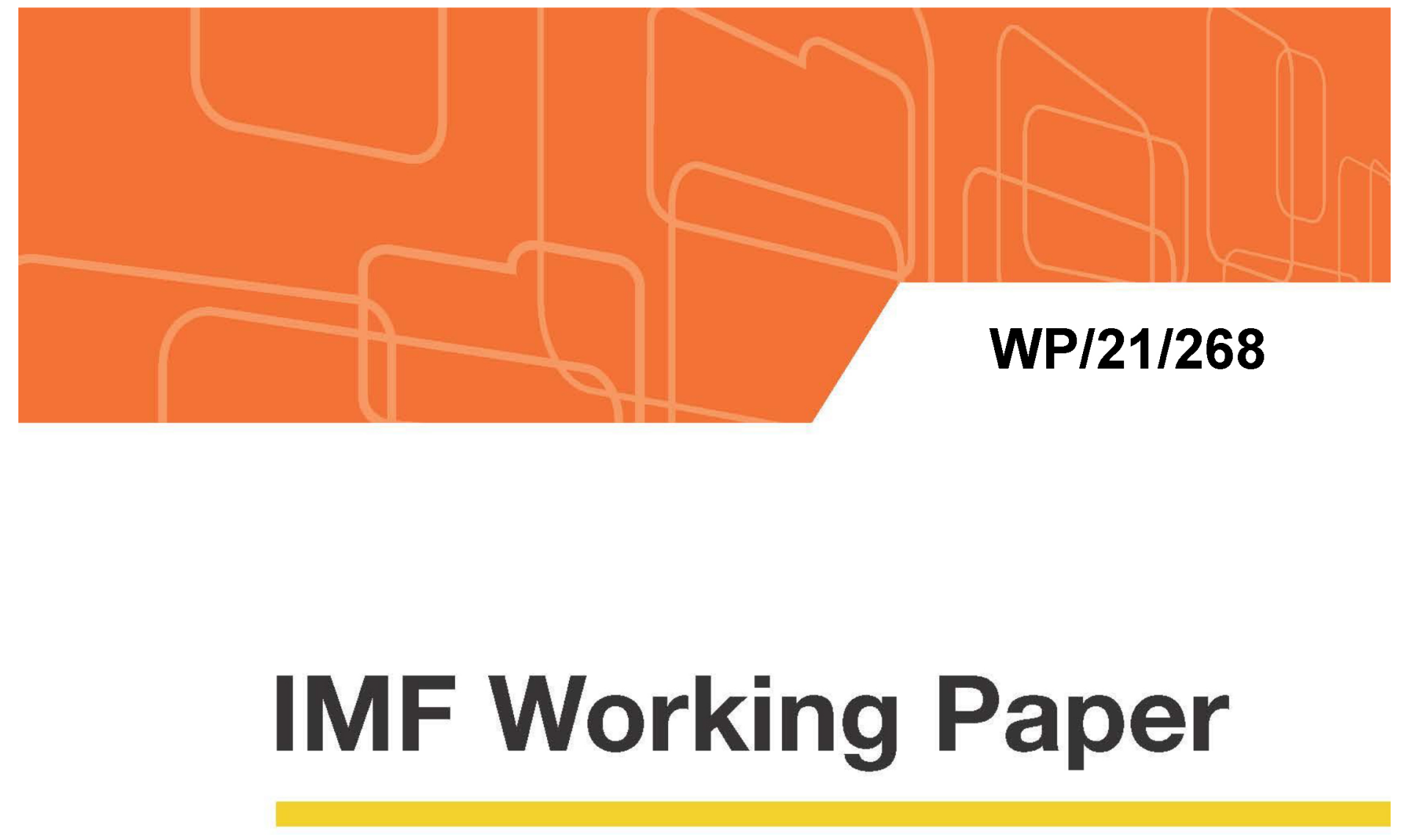

\title{
Establishing a Foreign Exchange Futures Market in China
}

\author{
by Zhongxia Jin, Yue Zhao, and Haobin Wang
}

IMF Working Papers describe research in progress by the author(s) and are published to elicit comments and to encourage debate. The views expressed in IMF Working Papers are those of the author(s) and do not necessarily represent the views of the IMF, its Executive Board, or IMF management. 


\title{
IMF Working Paper
}

Office of the Executive Director for China

\section{Establishing a Foreign Exchange Futures Market in China \\ Prepared by Zhongxia Jin, Yue Zhao, and Haobin Wang}

Authorized for distribution by Zhongxia Jin

November 2021

\begin{abstract}
IMF Working Papers describe research in progress by the author(s) and are published to elicit comments and to encourage debate. The views expressed in IMF Working Papers are those of the author(s) and do not necessarily represent the views of the IMF, its Executive Board, or IMF management.
\end{abstract}

\begin{abstract}
During China's transition toward a more flexible exchange rate, it is essential to further develop its foreign exchange (FX) derivatives markets to meet the growing hedging needs associated with greater exchange rate fluctuations. Although over-the-counter (OTC) FX derivatives markets already exist in China, it lacks a FX futures market that offers critical complementarities. With standardized products, greater transparency and centralized oversight, a FX futures market can better satisfy the hedging needs of small and mediumsized enterprises and enhance regulatory efficiency. To address concerns regarding whether FX futures market will amplify the volatility of spot exchange rates, this paper analyzes the impact of establishing FX futures markets on spot market volatility using data from major emerging market economies. The result shows that FX futures market is not empirically associated with an increase in spot market volatility; in some cases, it is even associated with a decrease in spot market volatility. This paper further suggests that for a well-functioning FX futures market to be established, it is essential for China to substitute the inefficient documentation requirement of underlying exposures with a new set of market-oriented measures for the purpose of prudent regulation.
\end{abstract}

JEL Classification Numbers: F31, G15, G28

Keywords: FX futures market, exchange rate, market-based regulation

Author’s E-Mail Address: ZJin@imf.org; YZhao3@imf.org; johnwhb@outlook.com 
Contents Page

Abstract $\quad \underline{\mathbf{2}}$

I. INTRODUCTION

II. WHY IS A FOREIGN EXCHANGE FUTURES MARKET NEEDED?

III. EMPIRICAL STUDY: "STABLIZERS” OR “RISK AMPLIFIER” $\quad \underline{8}$

IV. REGULATORY DESIGN

V. CONCLUSION

References $\quad \underline{21}$

Tables

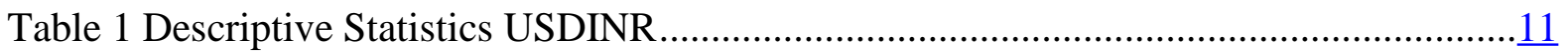

Table 2 The ADF test statistics value for USDINR ....................................................11

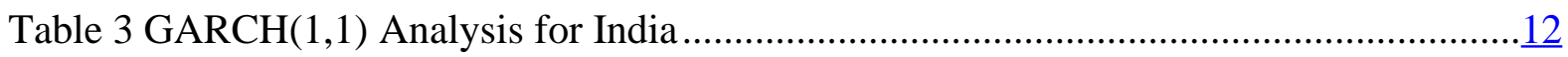

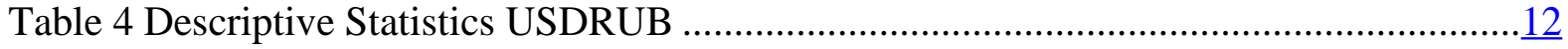

Table 5 The ADF test statistics value for USDRUB ……..............................................12

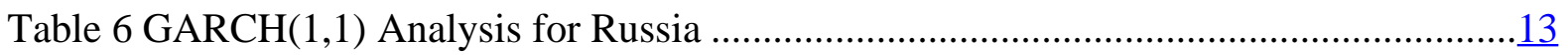

Table 7 Descriptive Statistics USDZAR........................................................................

Table 8 The ADF test statistics value for USDZAR.....................................................13

Table 9 GARCH $(1,1)$ Analysis for South Africa...............................................................14

Table 10 GARCH(1,1) Analysis for South Africa, Impact of Financial Crisis Controlled......15

Table 11 GARCH $(1,1)$ Analysis for India, Impact of Financial Crisis Controlled ...................15

\section{Figures}

Figure 1 FX Derivatives Coverage Ratio (2019） …….....................................................

Figure 2 Libor-OIS spread between 2006-2009 .................................................................14 


\section{INTRODUCTION ${ }^{1}$}

In recent decades, the Chinese authorities have been promoting market-friendly reforms to improve the flexibility of the exchange rate. Since 2016, the People's Bank of China has made a concerted effort to withdraw from daily interventions in the foreign exchange (FX) market and has significantly enhanced the flexibility of the RMB exchange rate. Looking ahead, it is in China's interest to further increase exchange rate flexibility and ultimately establish a floating exchange rate regime, which will lay the foundation for its further opening of the capital market and will pave the way for the internationalization of the RMB. Nevertheless, greater exchange rate fluctuations associated with a flexible exchange rate may have adverse impacts on the profits of exporters and importers and may increase the vulnerability of companies with large foreign debt exposures. This partly explains some emerging market economies' reluctance to convert to a floating exchange rate regime. International experiences suggest that it is crucial for a country to establish a FX derivatives market with sufficient depth and liquidity in order to successfully move toward a floating exchange rate regime while ensuring economic and financial stability. Although China has made great strides in developing its FX derivatives market in recent years, it still lacks an onshore FX futures market which typically forms a critical component of a well-functioning multi-layered FX market. Therefore, the FX derivatives market in China needs to be further developed in order to fully support a floating exchange rate.

Further development of the FX derivatives market will help build a solid foundation for enhancing exchange rate flexibility. The development of FX derivatives products, for instance, will help importers and exporters hedge risks from exchange rate volatilities to better overcome the "fear of floating." International experiences suggest that the risks associated with exchange rate fluctuations can be better managed through market tools rather than government interventions, and increased use of FX derivatives by trading companies can help improve the economy's resilience in response to external shocks. At the same time, for domestic economic entities with large foreign debt exposures, development of FX derivatives products will enhance their ability to hedge currency exposures, thereby enabling the economy to reduce the "balance sheet" effect of exchange rate fluctuations. A country with well-hedged foreign debt exposure and limited currency mismatches can remain resilient to even sizable exchange rate adjustments.

Although the over-the-counter (OTC) FX derivatives market already exists in China, it lacks a FX futures market that is of paramount importance for serving a wider range of market participants such as small and medium-sized enterprises (SMEs) and retail traders. At

\footnotetext{
${ }^{1}$ This work is the English version of a selected chapter from a research project sponsored by the China Finance 40 Forum (CF40). The work has benefited from comments and valuable discussions with participants at CF40's biweekly round table discussion. We would like to express our special thanks to Leo Melamed for his very valuable comments. We want to thank Kelly Eckhold, Asad Qureshi, Christian Saborowski and Jianping Zhou from IMF, Derek Sammann and Paul Houston from CME, Jing Hu and Lifeng Peng from PBOC, Chunying Wang from SAFE, Xiaohui Zhang from Tsinghua PBCSF, Yongding Yu from CASS, Fei Hou and Zhen Zhang from BOC, Ting Xiao from BCM, Shi Sha from CFFEX and Junjun Zhu from CEINEX for helpful suggestions. We would also like to thank Shuhan Jin from the University of Chicago and Xinyu Chen, Xinyi He and Alena Zhang for their excellent research assistances in this project, and Erin Yiu for editorial assistance.
} 
present, China's OTC FX derivatives market is mainly an inter-bank market offering products such as FX forwards, swaps, and options. The OTC market offers customized products that can meet the diverse needs of its customers. However, the main disadvantage of the OTC market lies in its high transaction costs, which has prevented some companies, especially SMEs, from participating in the market even when they face strong FX hedging needs. Compared with the OTC market, the futures market boasts many advantages, such as standardized and low-cost products, a centralized market with greater transparency, lower credit risk, and more effective supervision. These advantages will help serve the hedging needs of broader market participants, which can, in turn, help reduce exchange rate fluctuations in the spot market.

Despite the benefits of establishing an FX futures market, some policy makers have concerns about "speculative activities" of derivatives traders that may increase the volatility of underlying exchange rates. On the theoretical front, the impacts of the FX futures market on the spot market are two-fold. Some studies, as detailed in Section III, show that speculators will help stabilize the market by reducing the impact of one-way transactions on the market and will simultaneously increase market depth and reduce transaction costs. Other studies, on the other hand, suggest that high leverage and speculative activities in the derivatives market may amplify the risks in the spot market. Despite the diverse views in the theoretical literature, it is standard practice for a market to allow speculation as it is practically impossible to distinguish between "hedgers" with speculative intention and "speculators." The impact of speculation mainly hinges on specific conditions and regulatory practices in each country.

Unlike most existing literature analyzing the effects of derivatives market on developed countries, this paper focuses on emerging markets by studying whether the establishment of FX futures markets among BRICS countries increases the volatility of the underlying spot FX markets. Currently, China still requires documentation of underlying exposure for derivatives traders, which was also the case in other emerging market economies, such as India and South Africa before they established FX futures markets. In this regard, the experiences of developing countries are more relevant for China than those of developed countries. Our empirical results show that the establishment of the FX futures market did not increase the volatility of the spot market; on the contrary, it is empirically associated with a decrease in volatility in some cases. One possible reason is that the more diversified pool of participants, including speculators, help the exchange rate return to its equilibrium faster by "buying low and selling high," thereby generating a stabilizing effect on the market. The empirical finding is more apparent when we exclude the financial crisis period from the sample to better isolate the impacts of FX futures market. This implies that, for emerging market countries, the FX futures market acts more like a market stabilizer rather than a volatility amplifier.

In order for the FX futures market to become a stabilizer, it is essential to ensure the stability of the FX derivatives market through prudential regulation. China currently requires documentations of underlying exposure for derivatives traders, a regulatory approach that is not in line with international practice and can impede the development of China's derivatives markets. Hence, the near-term priorities for China include gradually phasing out the current 
requirement of underlying exposures and allowing for a more market-based approach to regulating market risks. For countries that have phased out the requirement of underlying exposure, regulators mainly resort to market-based regulatory measures such as margin requirement (leverage ratio), limitations on margins, position limits, and daily price bands to manage the risks of the futures market. Net settlement and local currency settlement can also minimize possible risks in the FX futures market.

The rest of the paper is organized as follows: Section II discusses the importance and urgency of setting up a FX futures market in China. Section III analyzes the impact of establishing FX futures markets on the volatility of spot markets in major emerging market economies. Section IV discusses how China should further reform financial regulations with the establishment of the FX futures market. Section V presents the conclusion.

\section{WHY IS A FOREIGN EXANGE FUTURES MARKET NEEDED?}

International experience has demonstrated the need - for both developed countries and developing countries - to establish a FX futures market during the movement toward a floating exchange rate. FX futures markets were first established in developed countries such as the United States, the United Kingdom, and Japan. In 1971, Milton Friedman offered support for developing a US-based currency futures market in a short article that arguably established the intellectual foundation for a FX futures market. Milton Friedman summarizes the key rationales for developing an onshore FX futures market in the US: promoting foreign trade and investment, strengthening the US financial services industry, reducing the volatility of cross-border capital flows, and facilitating the conduct of monetary policy.

For major developing markets, the transition toward a more flexible exchange rate was often accompanied by the rapid development of the FX futures market. Take Brazil for example. In January 1999, the Brazilian real was floated against the backdrop of continued depreciation pressure. The abandonment of the crawling peg led to sustained growth momentum in FX futures trading, with the trading volume growing tenfold between 1999 and 2008. Similarly in India, FX derivatives trading expanded rapidly alongside financial liberalization. Although trading in India's FX derivatives market was negligible before 1995, trading volume has started to grow rapidly since the Rupee's exchange rate became more flexible in 1995. In particular, the introduction of the onshore FX futures market had an impressive debut and has shown robust growth since its inception, with the annual turnover of exchange-traded options and futures rising sharply from 3.11 trillion Indian rupee in 2008/09 all the way to 98.96 trillion Indian rupee in 2011/12."

Although the OTC FX derivatives market in China has supported FX hedging for decades, the establishment of a FX futures market is urgently needed to encourage a broader range of market participants with hedging needs. At present, China's OTC FX derivatives market is mainly an inter-bank market offering tailor-made products to large companies and institutional clients. Notwithstanding the flexibility and diversity that the OTC market offers, its high transaction cost has prevented retail clients and SMEs from participating in the market. In recent years, the OTC market has started to tap electronic trading platforms and offer online products in order to help lower transaction costs for SMEs, yet problems such as high approval costs, nontransparent quotations, incomplete information coverage of clients, 
and a lack of centralized information still exist. Compared with the OTC market, the futures market — even with its relatively small size — has many advantages, as detailed next.

First, onshore FX futures market will likely become the single largest centralized FX trading platform, thereby effectively strengthening price discovery and improving market liquidity. Despite the size of the OTC market, it is typically fragmented with scattered bilateral transactions, which are not conducive to price discovery. In addition, bilateral transactions depend heavily on bilateral credit and, thus, are suitable for more developed countries with sound credit systems. In contrast, an onshore FX futures market can serve as the single largest centralized trading platform to facilitate price discovery, improve market transparency, and reduce credit constraints. International experiences suggest that the FX futures market has an advantage in offering short-term financial products whereas the OTC market does better in offering long-term financial products. In this regard, the FX futures market serves as an important complement to the OTC market.

Second, the onshore FX futures market can provide firms, especially SMEs, with low-cost tools to hedge exchange rate risks. Currently, China's FX derivatives coverage ratio, i.e., the ratio between FX derivatives trading and international trade, is low compared with other emerging market countries (Figure 1), in part due to the high hedging cost for firms, especially SMEs. The inter-bank OTC market mainly provides customized products catering to large firms and institutional clients, with little incentive for banks to provide better priced products for SMEs due to lack of competition. By contrast, the FX futures market treats each type of market participants equally by providing them with standardized and low-cost hedging tools. In recent years, exports from private enterprises dominated by SMEs have accounted for more than half of China's total exports. Hence, the FX risk management of SMEs has important macroeconomic implications for China's external risk exposure.

Figure 1 FX Derivatives Coverage Ratio（2019）

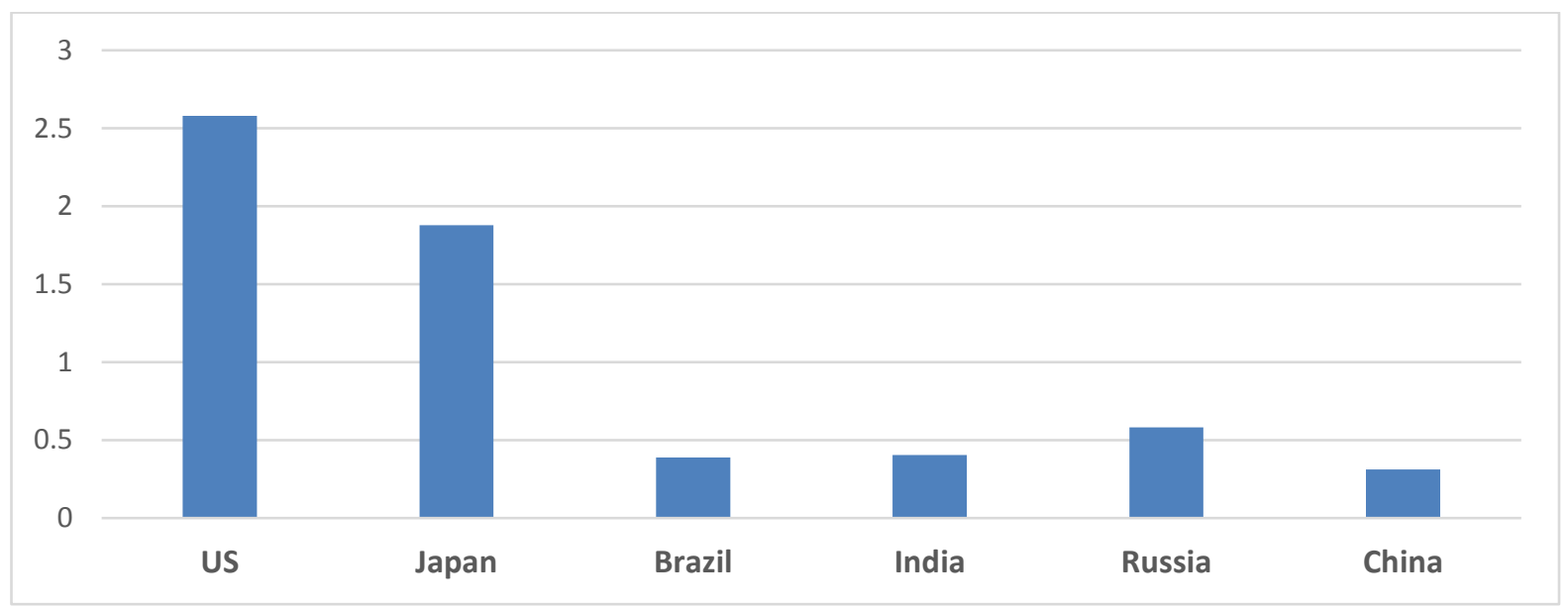

Source: IMF IFS, BIS, and staff's calculation.

Third, the onshore FX futures market can compete effectively with the offshore market to resolve regulatory challenges associated with an over-sized offshore market. In recent years, 
offshore RMB futures trading has grown rapidly, with daily trading volume exceeding US $\$ 4$ billion $^{2}$. As demonstrated by international experiences, an over-sized offshore market may bring about regulatory challenges such as increased volatility of cross-border capital flows, weakened capital flow management, and decreased domestic pricing power. The spillover effects from the offshore to the onshore market are most disruptive when the offshore market is large relative to the onshore market and when capital account restrictions create onshoreoffshore pricing gaps. In addition, due to the absence of a central clearing platform, a fragmented offshore market may reduce the effectiveness of price discovery and increase vulnerability to panics and liquidity squeezes when market conditions tighten. The development of a deep and highly liquid onshore market helps reduce the systemic risks and regulatory difficulties associated with offshore market volatility.

That being said, it should be clarified that the development of an onshore FX futures market is not intended to compete for the FX "pricing power" through administrative means. Instead, the aim is to cultivate and develop a deep exchange rate market with flexible and transparent prices that can accurately reflect market supply and demand. The pricing power is not controlled by administrative factors, but is rather determined by market participants. The market with de facto pricing power must be the one where the price can truly reflect the supply and demand.

Fourth, the establishment of the onshore FX futures market is in line with the G20's OTC derivatives reform agenda and will help strengthen the authorities' regulatory capacity in the FX market. Prudential regulation is essential to ensure the stability and sustainability of the FX derivatives market. The 2008 financial crisis demonstrated the vulnerabilities of the OTC derivatives market, such as the excessive accumulation of counter-party risk, a lack of transparency, and a range of operational deficiencies. In contrast, the FX futures market will ensure that most transactions are centrally settled, which will, in turn, effectively reduce the exposure of private sector counterparties, thereby mitigating macro-financial risks.

Finally, the establishment of onshore FX futures markets will enable cross-border investors to better manage the FX risk. Compared with the offshore FX futures market, the onshore FX futures market can better satisfy the hedging needs of international investors who invest in China's onshore bond and stock market. In addition, the establishment of onshore FX futures markets will also help decrease cross-border capital flows, since the establishment of an onshore FX will allow hedging activities to transfer to and from accounts within China, while the use of the offshore futures market by domestic traders and investors would produce more cross-border capital flows.

\section{EMPIRICAL STUDY: "STABLIZERS" OR "RISK AMPLIFIER"}

\footnotetext{
${ }^{2}$ Currently the largest two offshore RMB futures markets are Singapore exchange (SGX) and Hong Kong Exchanges and Clearing (HKEX), with average daily trading volume of US\$ 4.1 billion and 785 million respectively in May 2021.
} 


\section{A. Literature review}

On the theoretical front, there exist two opposing views in the literature regarding the impact of FX derivatives trading on the underlying spot markets. Some argue that the existence of derivatives markets helps stabilize exchange rates by reducing their fluctuations. A key feature of the derivatives market is the diversity of market participants, which includes not only hedgers but also speculators. In an efficient FX market, well-informed speculators make a profit by buying low and selling high, thereby helping stabilize the market by reducing the impact of one-way transactions (Friedman, 1953). When the demand for liquidity changes, the speculators, expecting that the exchange rate will eventually return to equilibrium, can take reverse positions that serve to reduce exchange rate fluctuations (Carlson and Osler, 2000). In addition, speculative activity serves to deepen the market and will make it easier for market participants to hedge at low costs (Friedman, 1953; Powers, 1970; Danthine, 1978; Bray, 1981; Kyle, 1985). The futures market can also enhance price discovery in the FX market and increase the amount of information reflected in prices (Stoll and Whaley, 1988).

By contrast, other studies argue that high leverage and speculation in the derivatives market may magnify risks in the spot market. Paul Krugman (1989) pointed out that some speculators are reluctant to assess whether the exchange rate is in line with long-term fundamentals and would instead try to predict and speculate on the views of other investors, which can lead to higher market volatility. At the same time, the high leverage and speculative nature of the derivatives market will inevitably attract some uninformed speculators who do not always "buy low and sell high," thereby reducing the information content of prices while increasing spot market volatility (Hart and Kreps, 1986; Stein, 1987).

Overall, the theoretical literature is inconclusive about the impact of the derivatives market on the spot market. Likewise, empirical research on this issue also produces no conclusive results. As Lee and Ohk (1992) point out, the impact of the derivatives market on the volatility of the spot market differs from country to country-not only because of the different structure of individual markets, but also due to country-specific conditions and the regulatory practices in each country. Clifton (1985) observed an increase in volatility in the currency spot market after the introduction of futures by using data from Chicago's International Monetary Market. Chatrath et al. (1996) and Shastri et al. (1996) studied the impact of the introduction of futures trading on the volatility in the spot rates of the British pound, Canadian dollar, Japanese yen, Swiss franc, and Deutsche mark, but the two papers had opposite findings. Whereas the former found that currency futures trading increased the volatility of exchange rates, the latter found that the volatility of exchange rates decreased following the introduction of FX derivatives.

Empirical studies have examined different countries, but most have focused on developed countries. A few papers investigate the effects of introducing FX futures markets in emerging economies (Jochum and Kodres, 1998; Oduncu, 2011; Nath and Pacheco, 2018), but they are mostly country-specific rather than cross-country studies. We conduct a cross-country analysis to investigate the effects of introducing currency futures on spot markets across several major emerging market economies in order to obtain results that are mostly relevant for China. 


\section{B. Data and methodology}

The historical time series of exchange rates are from Bloomberg. We use the daily closing values for the following currency pairs: USDINR, USDRUB, and USDZAR ${ }^{3}$. Our focus is on examining how exchange rate volatility changes before and after the introduction of FX futures market. To "identify" the introduction of the futures market, it is critical to choose an appropriate cutoff date that separates episodes with and without FX futures trading. As the futures markets in some countries experienced very low trading volume immediately after their introduction and only took off several years later, we chose a cutoff date that marks the beginning of a stable rise in currency futures trading. Accordingly, the cutoff dates for India, Russia, and South Africa were chosen as January 2009, January 2006, and January 2008, respectively. Both the Pre-cutoff-period (Pre-period for short in following contexts) and the Post-cutoff-period (Post-period for short in following contexts) are set to two years before and after the cutoff date ${ }^{4}$. Two years should be long enough to capture the effects of introducing currency futures, whereas periods longer than two years could incorporate more factors than the futures markets and be noisier.

The daily rate of return (of the local currency) is calculated by taking the natural logarithm of the ratio of the present day's index level with the previous day's index level. Before estimating the models, the unit root properties of each series are tested using ADF methods.

The volatility of the spot rate was modeled using the GARCH model for both the Pre-period and Post-period. GARCH models explain variance by two distributed lags. The first one, representing the autoregressive conditional heteroskedasticity (ARCH) effect, uses past squared residuals to capture news about volatility from the previous period, measured as the lag of the squared residuals from the mean equation. The second one is the lagged values of the variance itself and captures the long-term effect of the old news, representing the GARCH effect. The specification is shown in Equation (1) and Equation (2).

$$
\begin{gathered}
y_{t}=v_{t}+\varepsilon_{t} \ldots(1) \\
\sigma_{t}^{2}=\alpha_{0}+\alpha_{1} \varepsilon_{t-1}^{2}+\beta \sigma_{t-1}^{2} \ldots
\end{gathered}
$$

Parameter constraints:

$$
\begin{aligned}
& \alpha_{0}>0 \\
& \alpha_{1}>0
\end{aligned}
$$

\footnotetext{
${ }^{3}$ The case of Brazil is special. In 1987, Brazil established its FX futures market and the trading volume started to rise steadily in 1994. However, in 1994 Brazil also launched its official currency, the real. As a result, Brazil's FX fluctuations were more affected by changes in the exchange rate regime than by the establishment of the FX futures market. Therefore, Brazil is not included in our sample.

${ }^{4}$ In literature, there are typically two different approaches of determining the sample periods. One is to choose a fixed period before and after the cutoff date for each country, while the other is to choose the same period for all countries no matter what their cutoff dates are. We take the first approach to capture more country-specific factors.
} 


$$
\begin{gathered}
\beta \geq 0 \\
\alpha_{1}+\beta<1
\end{gathered}
$$

where $y_{t}$ represents the daily return series of the closing spot rate. $v_{t}$ is the intercept term, and $\varepsilon_{t}$ is the residual term of the mean model. $\alpha_{0}$ is the constant term of the conditionally heteroscedastic variance equation, $\varepsilon_{t-1}^{2}$ is the lagged squared error, and $\alpha_{1}$ (ARCH coefficient) shows the impact of current news on volatility. $\sigma_{t-1}^{2}$ is the lagged conditional variance, and $\beta$ represents the impact of old news on volatility, indicating the persistence of past information (the GARCH effect). Parameters $\alpha_{0}, \alpha_{1}$, and $\beta$ should be greater than zero for the conditional variance to be non-negative. In order to ensure that the conditional variance is covariance stationary, $\alpha_{1}$ plus $\beta$ should be smaller than one. The Lagrange multiplier (LM) test was conducted to determine the presence of the ARCH effect of the residuals.

\section{Empirical results and main findings}

\section{India}

Table 1 presents the descriptive statistics of the daily returns over the Pre-period and Postperiod. Table 2 shows the ADF test of the stationarity. The values of the t-statistics of USDINR during all the periods are statistically significant at the $1 \%$ significance level. Thus, this test confirms that all series under consideration are stationary.

Table 1 Descriptive Statistics USDINR

\begin{tabular}{|lccccc|}
\hline Variable & Obs & Mean & Std. Dev. & Min & Max \\
\hline Pre & 507 & -0.0001923 & 0.0047907 & -0.024074 & 0.0189109 \\
\hline Post & 485 & 0.0001808 & 0.0053458 & -0.0170301 & 0.0302912 \\
\hline
\end{tabular}

Table 2 ADF Test Statistics Value for USDINR

\begin{tabular}{|lcccccc|}
\hline & $\begin{array}{c}\text { Test } \\
\text { Statistic }\end{array}$ & $\begin{array}{c}1 \% \text { Critical } \\
\text { Value }\end{array}$ & $\begin{array}{c}5 \% \text { Critical } \\
\text { Value }\end{array}$ & $\begin{array}{c}10 \% \text { Critical } \\
\text { Value }\end{array}$ & $\begin{array}{c}\text { No. } \\
\text { Obs }\end{array}$ & $\begin{array}{c}\text { P } \\
\text { value }\end{array}$ \\
\hline Pre & -14.669 & -3.458 & -2.880 & -2.570 & 507 & 0.0000 \\
\hline Post & -16.165 & -3.460 & -2.880 & -2.570 & 485 & 0.0000 \\
\hline
\end{tabular}

The LM test for no ARCH effect of exchange rate returns is statistically significant with a zero probability, implying that there is a significant ARCH effect in exchange rate returns. The presence of heteroscedasticity in the exchange rate series shows the importance of using the ARCH family of models to study volatility. 
Table 3 GARCH $(1,1)$ Analysis for India

\begin{tabular}{|c|r|r|r|r|}
\hline & Intercept $(\alpha 0)$ & ARCH $(\alpha 1)$ & GARCH $(\beta 1)$ & \multicolumn{1}{c|}{$\alpha 1+\beta 1$} \\
\hline Pre-Derivative & $5.40 \mathrm{e}-07$ & 0.1595126 & 0.8292628 & 0.9887754 \\
\hline $\mathrm{P}$ value & 0.000 & 0.000 & 0.000 & 0.000 \\
\hline Post-Derivative & $3.08 \mathrm{e}-06$ & 0.1259465 & 0.7386511 & 0.8645976 \\
\hline P value & 0.000 & 0.000 & 0.000 & 0.000 \\
\hline
\end{tabular}

Table 3 lists the $\alpha_{1}$ and $\beta_{1}$ coefficients of the GARCH $(1,1)$ model, both of which are statistically significant at $1 \%$, suggesting that the volatility of $y_{t}$ is affected by recent information as well as past information. We found that, in comparison with Pre-period, both the recent information and the past information caused less volatility in the Post-period. We also examined the level of volatility in the Indian currency market using the unconditional variance calculated as the ratio of $\alpha_{0}$ to the difference between 1 and the sum of $\alpha_{1}$ and $\beta$ as follows:

$$
\operatorname{Var} \varepsilon_{t}=\frac{\alpha_{0}}{1-\left(\alpha_{1}+\beta_{1}\right)}
$$

The unconditional volatility of the GARCH process decreased from 0.00004810862 in the Pre-period to 0.00002274701 in the Post-period. These results show that the persistence of volatility decreased in the Post-period. The argument for the destabilizing effects of the currency futures markets is not supported in India's case.

\section{Russia}

As with India's case, we list the statistical summary and the results of the ADF test for Russia in Table 4. The table shows that all the series under consideration are stationary. Based on the results of the LM test shown in Table 5, the ARCH effect also exists in the exchange rate returns.

Table 4 Descriptive Statistics USDRUB

\begin{tabular}{|lccccc|}
\hline Variable & Obs & Mean & Std. Dev. & Min & Max \\
\hline Pre & 522 & 0.0000331 & 0.0019555 & -0.006682 & 0.006992 \\
\hline Post & 521 & 0.0002986 & 0.0021288 & -0.0073153 & 0.0098162 \\
\hline
\end{tabular}

Table 5 ADF Test Statistics Value for USDRUB

\begin{tabular}{|ccccccc|}
\hline & $\begin{array}{c}\text { Test } \\
\text { Statistic }\end{array}$ & $\begin{array}{c}1 \% \text { Critical } \\
\text { Value }\end{array}$ & $\begin{array}{c}5 \% \text { Critical } \\
\text { Value }\end{array}$ & $\begin{array}{c}10 \% \text { Critical } \\
\text { Value }\end{array}$ & $\begin{array}{c}\text { No. } \\
\text { Obs }\end{array}$ & $\begin{array}{c}\text { P } \\
\text { value }\end{array}$ \\
\hline Pre & -21.517 & -3.430 & -2.860 & -2.570 & 520 & 0.0000 \\
\hline
\end{tabular}




\begin{tabular}{|lllllll|}
\hline Post & -22.323 & -3.430 & -2.860 & -2.570 & 520 & 0.0000 \\
\hline
\end{tabular}

Table 6 lists the $\alpha_{1}$ and $\beta$ coefficients of the GARCH $(1,1)$ model, both of which are statistically significant at $1 \%$, suggesting that the volatility of $y_{t}$ is affected by recent information as well as past information. However, unlike India's case, the ARCH coefficient decreases while the GARCH coefficient increases. The sum of $\alpha_{1}$ and $\beta$ remains approximately unchanged. We then calculate the unconditional variance by dividing $\alpha_{0}$ by the difference between 1 and the sum of $\alpha_{1}$ and $\beta$. With the introduction of the currency futures market, the unconditional variance decreased from 0.00000546285 to 0.0000048643 . These results indicate that the change in the overall volatility in the post period, if any, is probably downward, which again is at odds with the concerns about the destabilizing effects of currency futures markets.

Table 6 GARCH (1,1) Analysis for Russia

\begin{tabular}{|c|c|c|c|c|}
\hline & Intercept $(\alpha 0)$ & ARCH $(\alpha 1)$ & GARCH $(\beta 1)$ & $\alpha 1+\beta 1$ \\
\hline Pre-Derivative & $8.60 \mathrm{e}-08$ & 0.1023693 & 0.881888 & 0.9842581 \\
\hline P value & 0.000 & 0.000 & 0.000 & 0.000 \\
\hline Post-Derivative & $4.71 \mathrm{e}-08$ & 0.0329523 & 0.9573649 & 0.9968879 \\
\hline P value & 0.281 & 0.017 & 0.000 & 0.000 \\
\hline
\end{tabular}

\section{South Africa}

Similarly, the time series of exchange returns in South Africa also shows stationarity and the existence of the ARCH effect, as seen in Tables 7 and 8.

Table 7 Descriptive Statistics USDZAR

\begin{tabular}{|lccccc|}
\hline Variable & Obs & Mean & Std. Dev. & Min & Max \\
\hline Pre & 521 & -0.0001554 & 0.0096418 & -0.032557 & 0.0277545 \\
\hline Post & 523 & -0.0001437 & 0.0163603 & -0.154965 & 0.0662992 \\
\hline
\end{tabular}

Table 8 ADF Test Statistics Value for USDZAR

\begin{tabular}{|lcccccc|}
\hline & $\begin{array}{c}\text { Test } \\
\text { Statistic }\end{array}$ & $\begin{array}{c}1 \% \text { Critical } \\
\text { Value }\end{array}$ & $\begin{array}{c}5 \% \text { Critical } \\
\text { Value }\end{array}$ & $\begin{array}{c}10 \% \text { Critical } \\
\text { Value }\end{array}$ & $\begin{array}{c}\text { No. } \\
\text { Obs }\end{array}$ & $\begin{array}{c}\text { P } \\
\text { value }\end{array}$ \\
\hline Pre & -23.344 & -3.430 & -2.860 & -2.570 & 520 & 0.0000 \\
\hline Post & -23.688 & -3.430 & -2.860 & -2.570 & 520 & 0.0000 \\
\hline
\end{tabular}


Table 9 lists the $\alpha_{1}$ and $\beta$ coefficients of the GARCH $(1,1)$ model, both of which are statistically significant at $1 \%$. The ARCH coefficients and GARCH coefficients go in opposite directions: The ARCH coefficients increased whereas the GARCH coefficients decreased, suggesting that the volatility coming from the new information increased while the volatility from the persistent old information decreased. Overall, the unconditional variance of the returns increased. Given that the currency futures in South Africa started to rise steadily in January 2008, that same year the financial crisis deepened around the globe, it is not surprising to witness the increasing volatility in exchange rate returns in the Post-period. This is in line with our results that the increased overall volatility comes from the new information.

Table 9 GARCH $(1,1)$ Analysis for South Africa

\begin{tabular}{|c|r|r|r|r|}
\hline & Intercept $(\alpha 0)$ & ARCH $(\alpha 1)$ & GARCH $(\beta 1)$ & \multicolumn{1}{c|}{$\alpha 1+\beta 1$} \\
\hline Pre-Derivative & $4.01 \mathrm{e}-06$ & 0.0322642 & 0.9247918 & 0.957056 \\
\hline P value & 0.250 & 0.098 & 0.000 & 0.098 \\
\hline Post-Derivative & $5.00 \mathrm{e}-06$ & 0.1492664 & 0.8454004 & 0.9946668 \\
\hline P value & 0.164 & 0.000 & 0.000 & 0.000 \\
\hline
\end{tabular}

\section{Robustness Check}

To control for the impact of the financial crisis between 2006 and 2009, we add an independent dummy variable named "financial crisis." To identify the financial crisis period, we used the spread between Libor and Overnight Indexed Swap (OIS) to proxy how severe the financial crisis was. Figure 1 shows a sharp rise in the Libor-OIS spread since September 2008, and the 6-month Libor-OIS spread stayed above 200 basis points from September to December 2008. Thus, we used a dummy variable with binary numbers 1 for the crisis period (September to December 2008) and 0 for the rest of the period between 2006 and 2009.

Accordingly, the GARCH variance equation was modified as follows.

$$
\sigma_{t}^{2}=\alpha_{0}+\alpha_{1} \varepsilon_{t-1}^{2}+\beta \sigma_{t-1}^{2}+\delta D F
$$

The empirical results after controlling for the crisis variable are shown in Table 10. Compared with Table 9, the ARCH coefficients and GARCH coefficients go in opposite directions: The ARCH coefficients increase whereas the GARCH coefficients decrease, suggesting that the volatility coming from the new information increases while the volatility from the persistent old information decreases. Overall, the unconditional variance of the returns decreases, which confirms our hypothesis that the increased overall volatility was mainly caused by the global financial crisis. After controlling for this effect, the exchange futures market reduced the overall volatility, contrary to concerns that derivatives markets are destabilizing.

Figure 2 Libor-OIS spread between 2006 and 2009 


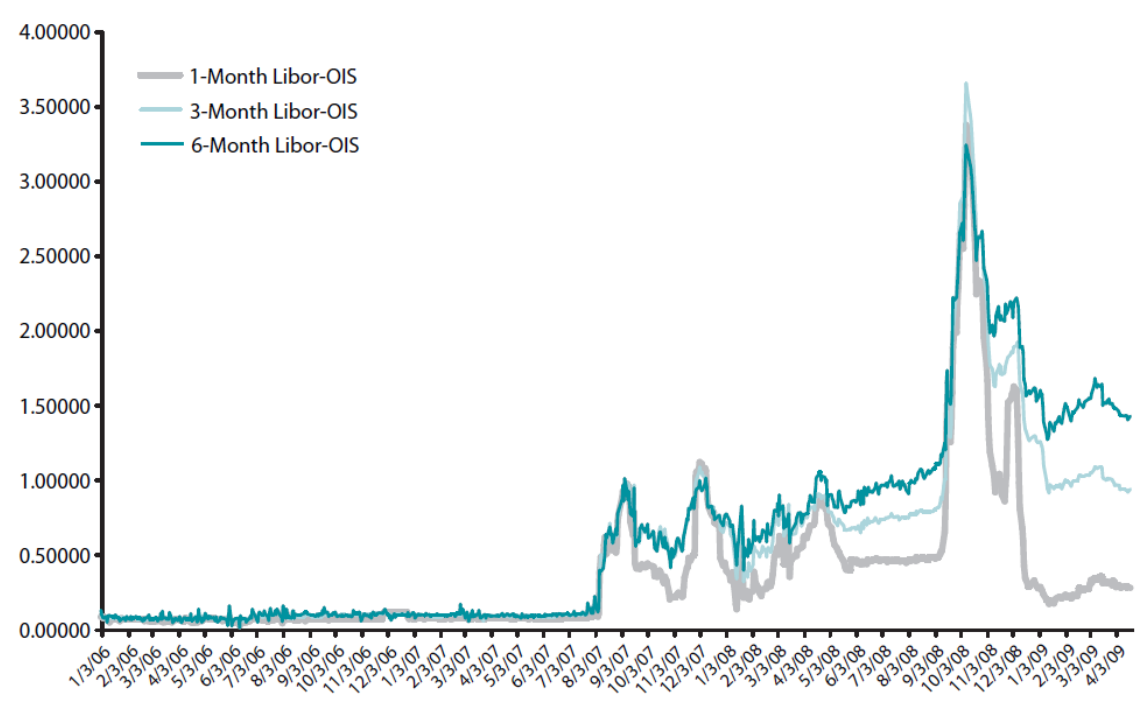

Table 10 GARCH $(1,1)$ Analysis for South Africa, Impact of Financial Crisis Controlled

\begin{tabular}{|r|r|r|r|r|r|}
\hline & Intercept $(\alpha 0)$ & ARCH $(\alpha 1)$ & GARCH $(\beta 1)$ & $\alpha 1+\beta 1$ & $\delta$ \\
\hline Pre-Derivative & $4.01 \mathrm{e}-06$ & 0.0322642 & 0.9247918 & 0.957056 & \\
\hline P value & 0.250 & 0.098 & 0.000 & 0.098 & \\
\hline Post-Derivative & 0.000275 & 0.0720019 & 0.8662979 & 0.9382998 & 1.876881 \\
\hline P value & 0.637 & 0.036 & 0.000 & 0.000 & 0.000 \\
\hline
\end{tabular}

For the robustness check, we also applied the financial crisis dummy for India, as the sample period ranging from January 2006 to December 2009 covers the financial crisis period. After introducing the financial crisis dummy in the variance equation for India, the results still hold for India (i.e., the introduction of the futures market reduced the overall volatility of the spot market). The results are shown below in Table 11 .

Table 11 GARCH (1,1) Analysis for India, Impact of Financial Crisis Controlled

\begin{tabular}{|c|c|c|c|c|c|}
\hline & Intercept $(\alpha 0)$ & ARCH $(\alpha 1)$ & GARCH $(\beta 1)$ & $\alpha 1+\beta 1$ & $\delta$ \\
\hline Pre-Derivative & -14.02913 & 0.1438344 & 0.8035084 & 0.9473428 & 2.168283 \\
\hline P value & 0.000 & 0.000 & 0.000 & 0.000 & 0.000 \\
\hline Post-Derivative & $3.08 \mathrm{e}-06$ & 0.1259465 & 0.7386511 & 0.8645976 & \\
\hline P value & 0.000 & 0.000 & 0.000 & 0.000 & \\
\hline
\end{tabular}




\section{REGULATORY DESIGN}

With the establishment of the FX futures market, the current requirement of underlying exposures should be gradually phased out. The requirement of underlying exposures in China once played an active role in informing regulators in a timely manner of the trade-based FX demand in the real sector. However, such requirement has become increasingly counterproductive to market development in recent years given increasing currency flexibility and more diversified currency demand.

First, the requirement of underlying exposure may result in trading in the same direction, thereby exacerbating pro-cyclical fluctuations of the FX market. As Friedman pointed out, although foreign payments are in balance over a long period (forward sales of currencies for hedging purposes just balance forward purchases for hedging purposes), there is nothing to ensure such a balance in the short term or for each foreign country separately. An active market needs speculators who are willing to take open positions as well as hedgers who have underlying exposure. Second, under the requirement of underlying exposure, the scale of onshore FX derivatives markets is limited the size of cross-border trade and investment. The requirement of underlying exposure will restrict the expansion of the onshore FX derivatives market by impeding market liquidity and depth, especially in countries with developed financial markets. Third, such a requirement cannot meet the needs of the traders who hedge FX risks in a preemptive manner, because documentation of underlying exposure can only happen after trade and investment transactions actually take place. Fourth, this requirement will mask rather than eliminate speculation, as can be shown in the large-scale capital flight when the exchange rate is significantly overvalued and excessive capital inflows when the exchange rate is significantly undervalued.

International experiences suggest that the establishment of the futures market can function as a starting point towards relaxing the requirement of underlying exposure. Take India as an example. Before the FX futures market was first established in 2008, the requirement of underlying exposure was in place, and market participants were only permitted to transact in derivatives markets to hedge an existing underlying exposure. Prior to the establishment of the FX futures market, the Internal Working Group on Currency Futures at the Reserve Bank of India (RBI) determined that the requirement of an underlying exposure could not remain valid under a futures regime, as futures by definition are meant to be used for both hedging and speculation. They recommended that the restrictions on trading purposes be modified and that OTC market restrictions also be removed in a phased manner. ${ }^{5}$ In accordance with the suggestions of the Internal Working Group, the requirement of underlying exposure was relaxed with the establishment of the FX futures market. Indian institutions and individuals could enter the FX futures market for hedging or other purposes without providing supporting evidence unless the volume of transactions reached a certain amount. The establishment of the FX futures market marked an important step forward in the RBI's liberalization in the FX derivatives market.

\footnotetext{
${ }^{5}$ For instance, if corporations were required to disclose unhedged exposures and the results of hedging, there would no longer be a need to verify the existence of an underlying commercial transaction.
} 
Currently, most developed countries allow speculators to participate in the FX futures market without any requirement of underlying exposure. Only a few developing countries maintain such requirements for certain segmented sub-markets. For countries without these requirements, regulators mainly take a market-based approach to manage risks, relying on tools such as leverage ratios, limitations on banks' financing, position limits, and daily price bands. Chinese regulators can similarly replace the current requirement of underlying exposures with market-based regulatory tools, which have proven to be broadly effective. To ensure compatibility with the existing FX regulatory framework, the FX futures market in China can be initially designed with local-currency-denominated cash settlement to avoid conflicts with the limit on individual FX purchasing. Next, we discuss some possible options towards adopting a market-based approach to regulate the FX futures market.

\section{Margin requirement (Leverage ratio)}

The primary purpose of a margin requirement is to protect the counterparty against an abrupt change in prices; regulators can also use it as a tool to adjust participants' leverage ratios. Insufficient margin requirement may result in increased market risks whereas excessive margin requirement may increase transaction costs and discourage trading. Cross-country data show that the margin requirements in emerging market economies lie within $5 \%-10 \%$, which implies a leverage ratio ranging from 10-20. Hence, the initial margin requirement in the case of China can be set at 5\% (allowing 20 times leverage) for most customers and 10\% (allowing 10 times leverage) for specific customers with higher risk profiles. This ratio can be adjusted over time based on market conditions and should gradually decrease as the FX futures market becomes more mature. In most developed economies, the margin requirement is usually less than 5\%. For example, the margin requirements of various USD/CNH Futures products in CME Group are between $1.5 \%$ and $2.4 \%$, the margin requirement of USD/CNH Futures in the Hong Kong Stock Exchange is around 2\%, and the margin requirement of USD/CNH Futures in the Singapore Exchange is about $1 \%$. These examples can provide a useful reference for adjusting the margin requirement as the onshore FX futures market gradually matures over time.

\section{Limitations on margin/net financial assets}

In addition to setting margin requirements, regulators could also place restrictions on the source of financing for the margin. Borrowed margin payments should be prohibited to reduce systemic financial risks. The margin of individual and institutional traders can be capped by a certain percentage of their net financial assets, with the aim of balancing their needs for FX hedging and potential risks from margin loss. The percentage of margin to participants' net financial assets can be set in different levels corresponding to different scales of net financial assets and different degrees of trading orientation.

\section{Position limits}

In order to prevent market manipulation and over-concentrated positions, position limits on market participants can be implemented. For example, India sets the gross open position limits of clients and members to $6 \%$ and $15 \%$ of total open interests respectively. China could 
also set position limits, beyond which a warning would be triggered for different types of market participants. The position limits could be dynamically adjusted as the market depth and liquidity increase.

\section{Settlement}

Cash settlements and physical delivery are two primary methods for settling a currency futures contract, each with its own advantages. Cash settlement is simpler and more convenient than physical delivery, while physical delivery can meet the actual currency needs of market participants. Cash settlement is more popular among speculators without actual currency demands and, consequently, amplifies the liquidity of the derivatives market. Cash settlement is also more suitable in countries without complete currency convertibility as it circumvents transactions involving foreign currencies. Across the world, physical deliverybased FX futures have been popular in countries with fully convertible currencies whereas countries with less than complete convertibility prefer cash-settled contracts.

Given the complications generated by delivery-based settlements and the fact that RMB is not fully convertible in the capital account, cash settlement in the local currency is an appropriate choice for China in the early stages of establishing a FX futures market. Cash settlement in the local currency can also help reduce risks and mitigate pressures on crossborder capital flows. International experiences suggest that the choice of settlement should be in line with a country's capital account opening process. As China continues to increase its capital account convertibility, the settlement method should also be adjusted accordingly.

\section{Daily price bands}

On the theoretical front, two opposing views have been put forth as to whether daily price bands should be set. Some believe that the price bands will impede the role of price discovery in the FX futures market; others argue that the price bands can curb irrational behavior and mitigate risks under market disorder. In practice, most developed and developing countries do not set daily price bands for their currency futures markets. India and Hungary are two of the few countries that set daily price bands. ${ }^{6}$ Currently, most offshore RMB futures markets do not have daily price bands. As China's central bank has withdrawn from regular interventions in the FX market, there is little need to impose daily price bands. An artificial price band may draw speculation and attacks and can cause differences between onshore and offshore prices. Meanwhile, it should be clearly stated to the market participants that the central bank is an active member of the FX futures market and reserves the right to intervene when necessary. In fact, central banks worldwide have adopted a variety of temporary measures to curb speculation and maintain financial stability under disorderly market conditions. ${ }^{7}$

\footnotetext{
${ }^{6}$ India sets different percentage limits for contracts with different durations, while the Budapest Stock Exchange in Hungary sets daily maximum volatility based on the absolute change of the exchange rate rather than on a certain percentage.

${ }^{7}$ For example, during the 2011-2012 rupee crisis, the RBI adopted measures, such as reducing position limits and curbing banks from arbitraging between the FX futures markets and OTC markets. In times of financial market volatility in March 2020, many countries temporarily intervened in the FX market or restricted shortselling.
} 


\section{Role of central banks and supervisory authorities}

The supervision of the FX futures market is a very nuanced area and pertains to the responsibilities of multiple regulatory bodies; as such, coordination among different regulatory agencies is indispensable. The nature of the FX futures market (i.e., financial derivatives with the exchange rate as the underlying asset) requires joint oversight by the central bank and the securities regulatory commission. Based on international practices, the central bank should be responsible for providing market access guidance, monitoring market participants' sources of financing, and dynamically setting trading parameters, such as participants' margin requirements and position limits. In addition, the central bank can directly participate in the FX futures market as an active member and can opt to intervene under disorderly market conditions. In addition, the securities regulatory commission is responsible for enforcing regulations and standards for market participants under its supervisory purview. The effective coordination across different regulatory bodies will play an important role in safeguarding the stability of the FX futures markets.

A well-functioning FX futures market also requires more widespread use of derivatives tools by market participants. Currently, China's usage of FX derivatives is still lower than its peers, partly due to the insufficient adoption of "hedge accounting." Hedge accounting can help firms avoid large fluctuations in profits caused by the repeated adjustments of financial derivatives' values. Broad practice of such accounting method can help mitigate enterprises' concerns about the volatility of financial derivatives and the ensuing financial losses that may hurt their competitiveness. To further encourage Chinese enterprises to adopt hedge accounting, regulators should educate enterprises and investors to have a risk-neutral perspective and focus on the core business instead of the profits and losses caused by financial derivatives. Enterprises and investors should be informed that financial derivatives can help the firms obtain stable returns and are financially neutral in the long run.

The discussion of FX futures markets in this paper has focused on their essential characteristics - namely, high levels of standardization, low access barriers, greater transparency, and strong oversight. As for the question of which specific platform should be used for FX futures markets, countries should be granted the flexibility to make their specific choices. In China, the FX futures market can be established through either the inter-bank market or the exchange-traded market. Each platform has its own advantages and disadvantages.

Although most FX futures markets worldwide have been established in an exchange, similar platforms may face significant challenges in China. Compared with the inter-bank market, the exchange has often regulated margin trading for a few decades and served diversified market participants, including individuals, to encourage competition. However, the main problem with an exchange is the difficulty in boosting market liquidity at the early stage of establishing the market. The onshore FX futures market will inevitably face fierce competition from the existing OTC market and offshore FX futures market given the similarities of their products. It will be very difficult for the FX futures market to thrive or even survive if market liquidity is insufficient. Japan, Australia, and many European 
countries all experienced a thin or shrinking market right after the establishment of futures markets. Given the relatively small size of the FX futures market, ${ }^{8}$ insufficient liquidity may become a significant obstacle to China's efforts to establish an FX futures market. Therefore, the criteria for platform selection should prioritize liquidity and development considerations.

Accordingly, China could consider setting up a FX futures market based in the inter-bank market to avoid insufficient liquidity at the early stage, given that commercial banks in China are the largest participants of the FX market. One major advantage of establishing an FX futures market based in the inter-bank market is the ability to fully mobilize the banks' participation. Banks, with their vast customer resources, could help improve the liquidity of the futures market and market efficiency, preventing the FX futures market from failing at the outset. This design is also in line with the inclusive nature of the futures market in that it helps the forward market and the futures market to complement instead of competing with each other. Currently, inter-bank market participants are accustomed to making FX transactions, and the financial infrastructure in the inter-bank market is also advanced enough to facilitate the establishment of the market.

No matter which platform is used, it is critical to allow all types of market participants to access the market at its inception. All institutions and individuals with exchange rate exposures should have access to the FX futures market and should be regulated on a marketbased approach. The platform should have an electronic one to cross geographical boundaries and encourage participation from any corner of the world. The more diverse market participants are, the more valuable and informative the price will be. Commercial banks and other institutions should also be allowed to enter both the OTC market and the futures market as market makers and arbitrageurs to narrow the spread between the two markets.

\section{CONCLUSION}

International experience suggests that the FX futures market plays an important role in serving a vast number of investors and improving price discovery. It is an important supplement to the spot and OTC markets. A major concern of regulators is whether the establishment of the FX futures market would amplify the volatility risk of underlying exchange rate. Based on empirical studies of several major developing countries, this paper shows that the volatility of the spot market has not increased with the establishment of the FX futures market, and some countries have even seen a reduction in the volatility of the spot market. In this regard, the FX futures market functions more like a "stabilizer" than a "risk amplifier." Going forward, it is in China's interests to accelerate the establishment of a FX futures market and to allow for a more market-based approach to ensure the stability and sustainability of such a market.

\footnotetext{
${ }^{8}$ According to the Chicago Mercantile Futures Exchange, the FX futures market only accounts for about 5\%$10 \%$ of foreign exchange derivatives transactions.
} 


\section{REFERENCES}

Adrian, T., and Shin, H. S., 2014, Procyclical leverage and value-at-risk. The Review of Financial Studies, 27(2), 373-403.

Bray, M., 1981, Futures trading, rational expectations and the efficient market hypothesis. Econometrica, 49: 575-96.

Carlson, J. A., and Osler, C., 2000, Rational speculators and exchange rate volatility. European Economic Review, 44(2), 231-53.

Chatrath A., Ramchander, S., and Song, F., 1996, The role of futures trading activity in exchange rate volatility. Journal of Futures Markets, 16: 561-84.

Chicago Mercantile Exchange Group, 2017, Clearing Risk Management and Financial Safeguards, CME Group Report.

Clifton, E., 1985, The currency futures market and interbank FX trading. Journal of Futures Markets, 5: 375-84.

Danthine, J., 1978, Information, futures prices and stabilizing speculation. Journal of Economic Theory, 17: 79-98.

Friedman, M., 1953, 'The case for flexible exchange rates', in Essays in positive economics, University of Chicago Press, Chicago, pp. 157-203.

Gopinath, S., 2010, Over-the-counter derivative markets in India-Issues and perspectives. Financial Stability Review.

Hart, O., and Kreps, D., 1986, Price destabilizing speculation. Journal of Political Economy 94(5): 927-52.

Jin, Z., Wang, H., and Zhao, Y., 2021, The macroeconomic impact of FX intervention: Some cross-country empirical findings. IMF Working Paper.

Jin, Z., Zhao, Y., and Wang, H., 2021, RMB: from marketization to internationalization. China Financial Publishing House (in Chinese), Beijing, China.

Jochum, C., and Kodres, L., 1998, Does the introduction of futures on emerging market currencies destabilize the underlying currencies?. IMF Staff Papers, 45(3): 486-521.

José L. R., 2007, The use of currency derivatives by Brazilian companies: An empirical investigation. Brazilian Review of Finance, Brazilian Society of Finance, 5(2): 20532.

Krüger, M., 1996, Speculation, hedging and intermediation in the FX market (No. 9606).

Krugman, P., 1989, The case for stabilizing exchange rates. Oxford Review of Economic Policy, 5(3): 61-72. 
Krugman, P., and Taylor, L., 1978, Contractionary effects of devaluation. Journal of International Economics, 8(3): 445-56.

Kyle, A., 1985, Continuous auction and insider trading. Econometrica, 53: 1315-35.

Lee, S. and Ohk, K., 1992, Stock index futures listing and structural change in time-varying volatility. The Journal of Futures Markets, 12: 493-509.

Nath, G., and Pacheco, M., 2018, Currency futures market in India: an empirical analysis of market efficiency and volatility. Macroeconomics and Finance in Emerging Market Economies, 11(1): 47-84.

Oduncu, A., 2011, The effects of currency futures trading on Turkish currency market. Journal of BRSA Banking and Financial Markets, Banking Regulation and Supervision Agency, 5(1): 97-109.

Powers, M., 1970, Does futures trading reduce price fluctuations in the cash markets?. American Economic Review, 60: 460-4.

Prakash, A., 2012, Major episodes of volatility in the Indian FX market in the last two decades (1993-2013): Central Bank’s Response. Reserve Bank of India Occasional Papers, 33(1 \& 2).

Reserve Bank of India, 2008, "Report of the internal working group on currency future.

Shastri, K., Sultan, J., and Tandon, K., 1996, The impact of the listing of options in the FX market. Journal of International Money and Finance, 15: 37-64.

Stein, J., 1987, Informational externalities and welfare reducing speculation. Journal of Political Economy, 95: 1123-45.

Stoll, H., and Whaley, R., 1988, Volatility and futures: Message versus messenger. Journal of Portfolio Management, 14(2): 20-2. 